\title{
Генерация второй гармоники в пленках донорно-акцепторный хромофор-полимер при повышении температуры в процессе полинга
}

\author{
В.В. Шелковников, Н.В. Васильева, Е.В. Васильев, И.Ю. Каргаполова, С.В. Коротаев, Н.А. Орлова \\ Новосибирский институт органической химии им. Н.Н. Ворожчова СО РАН, Новосибирск, \\ 630090, пр. ак. Лавреньева, 9 \\ тел:+7 (383) 330-89-96, факс:+7 (383) 330-97-52, эл.nочта: vice@nioch.nsc.ru
}

DOI 10.34077/RCSP2019-44

В последние десятилетия нелинейно-оптические (НЛО) хромофор-полимерные материалы привлекают внимание благодаря большому потенциалу применения в устройствах фотоники и электрооптики [1-2]. По сравнению с неорганическими материалами органические НЛО-материалы имеют ряд преимуществ: они легкие, недорогие, имеют большую эффективность генерации второй гармоники и хорошую технологичность формирования планарных элементов. Для проявления НЛО отклика системы хромофор-полимер - «гость-хозяин» проводят ориентирование диполей хромофора в полимерной матрице путем полинга материала при приложении внешнего электрического поля, например, коронного разряда.

В работе проведено исследование условий полингования полимерной системы гость-хозяин при измерении сигнала генерации второй гармоники одновременно с повышением температуры матрицы в области коронного разряда системы полингования.

В качестве гостя использовали донорно-акцепторный краситель, полученный на основе полифторзамещенного триарилпиразолина (донорный блок) и дицианоизофороновой группы (акцептор), в качестве матрицы хозяина использовали полимер поликарбонат. Упрощенно полифтортриарилпиразолин-дицианоизофорон-поликарбонат (ПФТАП-ДЦИ-ПК).

Созданная экспериментальная установка позволяла проводить полингование экспериментальных образцов при нагревании от 25 до $200{ }^{\circ} \mathrm{C}$ и одновременное формирование коронного разряда на поверхности полимерной пленки. В процессе полинга осуществлялось облучение образца импульсами (5.6 мДж, 3.7 нс) первой гармоники (1064 нм) Nd:YAG лазера. Возникающее излучение второй гармоники образца (532 нм) выделяли и регистрировали спектрометром. На рис. 1 приведен спектральный отклик второй гармоники, регистрируемый в процессе полинга ПФТАП-ДЦИ-ПК.

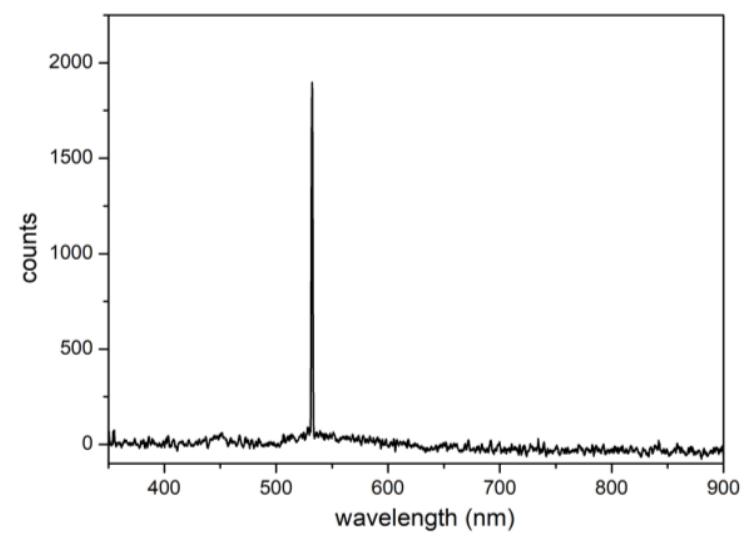

Рис. 1. Спектральный отклик образца при генерации второй гармоники.

Для образцов ПФТАП-ДЦИ-ПК были сняты температурные зависимости эффективности генерации второй гармоники в процессе полинга, при этом в образцах варьировали:

- массовую долю красителя от 5 до 20 \% масс;

- толщину полимерного слоя от 0.9 до 2 мкм.

Полученные температурные зависимости эффективности генерации второй гармоники в процессе полинга и возникающие эффекты обсуждаются в докладе.

\section{Литература}

[1] А. Д. Гришина, Л. Я. Перешивко, Т. В. Кривенко, В. В. Савельев, Б. И. Шапиро, А. В. Ванников, Изв. АН. Сер хим, 1999, 86.

[2] P. M. Ushasree, M. Szablewski, Opt. Photonics J., 2016, 6, 101. 